Litinfinite Journal

ISSN: 2582-0400 [Online]

CODEN: LITIBR

Vol-2, Issue-1 ( $2^{\text {nd }}$ July, 2020)

Page No: 62-67

DOI: 10.47365/litinfinite.2.1.2020.62-67

Section: Interview

\title{
An interview with Dr. Santosh Alex
}

\author{
Sreetanwi Chakraborty \\ Assistant Professor \\ Amity Institute of English Studies and Research \\ Amity University Kolkata \\ E mail I.d.: schakraborty3@kol.amity.edu
}

\begin{abstract}
:
In the given interview, poet, writer and translator Dr. Santosh Alex, who is an author of 42 books over the span of several years. In the given interview, he talks about poetry, translation, multilingualism and its features. Along with that, there is also a discussion area about the differences that might arise in case of stories, poems and novels. He also talks about the women poets of Kerala and how his books in English, Hindi and Malayalam have reached have gained popular readership. He also talks about the linguistic narratives that are part of any dominant social structure. Moreover, he also talks about translation and retention of the original flavour of any language.
\end{abstract}

Keywords: Translation, Poetry, Multilingualism, Indian Poetry, Indian English

Dr Santosh Alex is the author of 42 books and is a bilingual poet, widely published translator and a poetry curator from India. His books include poems, translations and criticism. His poems have been translated into 30 languages world over. His poems have been published in International Poetry Anthologies like Sunrise from the Blue thunder(America), Hudson View(South Africa), Indo Australian Poetry Anthology( Australia), Poems for Hazara (Afghanistan), XX1st Century Literature(India), Salt Boundaries(Turkey) and other reputed English journals. His major works include three poetry collections in Malayalam titled Dooram (2008) and Njan Ninakku Oru Ghazal (2013) and Ittuliyum Pathuliyum (2020), Three poetry collections in Hindi titled Panv Tale kimitti (2013),Hamare Beech Ka Maun (2017) and Pitha Mere (2020) one in English titled Alone with Everybody (2016).Dr Santosh Alex is enriching Indian Literature by means of translation and creative writing for the past two decades. He was awarded Pandit Narayan Dev Puraskaar(2004), Dwivageesh Puraskaar (2008), Thalashery Raghavan Memorial Poetry Award(2015), Sirjanlok Poetry Award(2015), Sahitya Ratna Puraskaar (2016), Vitruso International Poetry Award (2018) and P.C. Joshy, Shabd SadakAnuvadak Samman (2018).He works as a Hindi Officer in a Research Institute in Cochin, Kerala. He can be reached at drsantoshalex@ gmail.com

Professor Sreetanwi Chakraborty in conversation with Dr Santosh Alex, India's widely published Translator and Scholar in Translation

1. Over the span of several years, you have authored 42 books in three languages Viz English, Hindi and Malayalam and you are a widely published multilingual translator in India. Could you throw light on as to how did you venture into translation?

Note: This is an interview and there is no citation or works cited required. It is a live interview taken by Sreetanwi Chakraborty, Chief-Editor of Litinfinite Journal. 
Litinfinite Journal

ISSN: 2582-0400 [Online]

CODEN: LITIBR

Vol-2, Issue-1 ( $2^{\text {nd }}$ July, 2020)

Page No: 62-67

DOI: 10.47365/litinfinite.2.1.2020.62-67

Section: Interview

It's been 28 years since I am into the field of translation. Venturing into the field of translation was an accident. When I finished my M.A. in Hindi from Cochin University, kerala, I had to stay back in the University to complete my Diploma course in Translation. The classes for Diploma were in the morning from 8.00 a.m. to 10.a.m. and the rest of the day I was free. So one day I thought to translate one Malayalam short story into Hindi. It was also to put into practice the theory I learnt in the translation class.

The short story I chose to translate from Malayalam to hindi was titled Thiruthu (Correction) in Malayalam and was written by renowned short story writer N.SMadhavan. It was difficult to translate, but somehow I finished it. I approached my Professor and guru Dr Aravindakshan Sir, he gave me several tips to translate and instructed me to choose small stories for translation. That's how I translated the short story of Madhavikutty titled "Koladu" into Hindi and then continued to translate more stories, then went on to translate poems and then novels.

2. You have translated 6 novels from Malayalam to Hindi and also translated 11 young woman poets from Malayalam to English titled Woman poets of Kerala : New Voices. Tell us something about these.

The Malayalam novels I translated into Hindi are of PunathilKunhabdullah titled “Aligarhkakaidi”,Ambikasudan Mangad's novel titled "Enmakaje”, Sethumadhavans novel titled "Sanket" and three novels of Vaikom Mohammad Basheer in Hindi titled Basheer teen upanyas. Punathils novel is based on his student days when he was studying for MBBS in Aligarh. Enmakaje has 18 reprints in Malayalam so far. The novel was a milestone in the struggle for justice to the victims of Endosulfan, a pesticide that was air sprayed on state run cashew plantations in Kerala.The three novels by Basheer was a challenge especially Anavarium Ponkurishum (Elephant scooper and the Golden cross )

Woman poets of Kerala: New Voices was an attempt to introduce 11 young woman poets to the English speaking readers. I am happy that the book was received well and majority of these poets are today well known poets in Malayalam.

Translating poems are more difficult than fiction and is a challenge. Its difficult to transport a poem from its linguistic terrain in the source language and introduce it into a new terrain and blend it with the target language.

3. What are the specific regional subjects you gravitated toward when you started translating?

I had no specific subjects in mind when I started translation. I started translating from Malayalam to Hindi and then from Malayalam to English. Later I translated Telugu stories to Hindi, then went on to translate Jayant Mahapatras selected poems into Hindi, later translated Jnanpith Awardee Kedarnath Singh's selected poems into Malayalam. So nothing was planned. I went on translating and the number of books kept on increasing.

Note: This is an interview and there is no citation or works cited required. It is a live interview taken by Sreetanwi Chakraborty, Chief-Editor of Litinfinite Journal. 
Litinfinite Journal

ISSN: 2582-0400 [Online]

CODEN: LITIBR

Vol-2, Issue-1 ( $2^{\text {nd }}$ July, 2020)

Page No: 62-67

DOI: 10.47365/litinfinite.2.1.2020.62-67

\section{Section: Interview}

4. Your books on translation in Hindi titled Anuvad: PrakriyaEvamVyavahariktha is included in the syllabus of three universities in the country. Tell us something about the book.

Well, this is an academic book on translation studies. I have tried to explain the problems of translation in English, Hindi and Malayalam and have tried to give few solutions. Problems on cultural equivalents, idioms and phrases and translation of fiction and poetry are discussed in the book with examples.

5. Where do you see translation in current times? What can be some of the major impediments that you face while translating?

In a multilingual country like India translation plays an important role. Earlier translation was taught along with comparative literature, but today it's become an independent discipline. Today, in the age of globalization, the scope of translation is immense. The significance and relevance of translation in our daily life is multi-dimensional and extensive. Translation helps us to know about the developments in the field of creative arts, education, literature, business, science and politics. Translation and translators build socio-cultural bridge between communities and countries.

There are many impediments one faces while translating. The most important one being the translation of cultural equivalents. Cultural understanding during the process of translation is very essential especially in the translation of literary texts, which requires an effort on the part of the translator to retain the cultural information of the source text in the target text. Hence cultural translation is known to be one of the most challenging aspects of translation. It involves the translation of linguistic structures as a part of culture, in which the translator takes into account the equivalence of meaning and also investigates higher levels of context, semantics, content and pragmatics.

Apart from the cultural equivalents the syntax and the style of the language also counts in the process of Translation. Translation is not as easy as its seems to be, it's a creative process where in a new life is given to the source text.

6. Do you think the inclusion of translation as part of academia can enrich future readers, learners and academicians? In what way?

Like I said before, Translation is an independent discipline today. With the rapid inflow of MNCs into the country due to the globalization of Indian economy and the increasing need for translation in sectors like Universities, publishing houses, research organizations, medical science, tourism, entertainment, public relations and mass communication, international organizations, embassies, diplomatic service and BPO's have strengthened the importance of translation. Hence including translation as a part of academic would definitely help the students to fetch a job.

\section{Can there be a complete justice done to any original work through translation?}

Translation is a tedious process. Writing is creation. Translation is re-creation. Hence to recreate the text given from the source language to the target language needs a lot of expertise

Note: This is an interview and there is no citation or works cited required. It is a live interview taken by Sreetanwi Chakraborty, Chief-Editor of Litinfinite Journal. 
Litinfinite Journal

ISSN: 2582-0400 [Online]

CODEN: LITIBR

Vol-2, Issue-1 ( $2^{\text {nd }}$ July, 2020)

Page No: 62-67

DOI: 10.47365/litinfinite.2.1.2020.62-67

Section: Interview

and experience. According to me if a translator can achieve more than eighty percent in translation, then it's a good achievement. Anything beyond eighty percent would be a bonus.

Renowned Translation Scholar Lawrence Venuti speaks about "Invisibility in Translation". He opines that the translation should read like the original, wherein the Translator remains invisible. This is a difficult task as far as translation is concerned, but there are cases where the translation was very close to the original. All said and done, translation builds bridges between two languages and two cultures and broadens our sphere of knowledge.

8. Over the span of 28 years, you have authored 42 books and you are a widely published translator. What are some of the inputs that you can give to new translators, or those who are interested in translation works?

Translation is not everybody's cup of tea. It needs years and years of hard work and practice to excel in translation. Read a lot of translated literature which are done by reputed translators. There are very bad translations also available in the market, you need to keep away from them.Its because many times the Assignment and the Projects are given to the translators those who have no interest in Literature, for them it's an opportunity to make some money and in such cases, the end result has been devastating. Those who want to involve themselves with translation, develop your vocabulary and the knowledge of cultural implications of the language, which will help you in the translation process.

9. Tell us about the main literary components of your poetry collection Dooram (2008) and Njanninakkuorughazal (2013 ), IttuliyumPathuliyum (2020)in Malayalam and three poetry collection in Hindi Panv Tale kimitti ( 2013), Hamare Beech Ka Maun (2017) and Pitha Mere ( Long poem, 2020)

My Malayalam and Hindi poems speak of Nature and Humanism. Many of the poems speak about nature and the relations between man and nature. Also they speak about the humanism aspect.

The poem "Pitha Mere" is a long poem and has been published last week from Delhi. This poem is about me, my father, my family, my writings, my siblings etc. Even though it's a lengthy poem with 11 sections, in totality it is read as a single poem. Hope like other two poetry collections this too would be well received by the readers.

10. Apart from the Pandit Narayan Dev Puraskaar (2004),DwivageshPuraskaar(200809)SahityaRatnaPuraskaar (2016) and the DwivageeshPuraskaar (2008), you have also been honoured with the prestigious International Vitruvio Award from Italy. How have these awards enriched your own learning sphere and spaces of inspiration?

In the past 28 years I have never tried for any award. If there was an announcement and I find myself suitable for it, I have applied. I have won and I have lost many times. But that doesn't matter. Dwivageesh puraskaar, the National Award for translation was awarded to me by the prestigious Bhartiya Anuvad Parishad, New Delhi. I was the youngest translator to receive the National Award at the age of 38 and I am happy that I still hold the record. The International Vitruvio Award from Italy was for the translation of my poem in Italy, translated by my poet friend Claudia Piccino.

Note: This is an interview and there is no citation or works cited required. It is a live interview taken by Sreetanwi Chakraborty, Chief-Editor of Litinfinite Journal. 
Litinfinite Journal

ISSN: 2582-0400 [Online]

CODEN: LITIBR

Vol-2, Issue-1 ( $2^{\text {nd }}$ July, 2020)

Page No: 62-67

DOI: 10.47365/litinfinite.2.1.2020.62-67

Section: Interview

Awards are always a source of inspiration. As a writer and translator it would make you more responsible and eventually the task should be to introduce good writers through translation.

11. You are a poet, translator and a poetry curator. Please throw light on the curation of poetry and Cochin Litfest.

I was fortunate enough to have curated the first three editions of A.AiyappaPatana Kendra Poetry Fest. Also I was fortunate to curate three session for the inauguraledition(2017)of KritiLit fest organized by the Government of Kerala.

I am the founder of Cochin Lit fest, which has completed three editions so far, beginning from 2017. Cochin Lit fest provides platform for budding writers and established writers. Many young writers have been a part of the Litfest. It has been a good journey so far.

12. Litinfinite is a bilingual journal that offers a literary platform for both Bengali and English writers and researchers. Do you have any suggestion for our writers, researchers and readers?

Litinfinite is doing a good job by providing platform for Bengali and English writers and researchers. My suggestion would be to read more and write less. The new generation wants to write more and read less. Hence the pitfall in their writings is evident. If you want to become a master, then read your masters. Wishing good luck to Litinfinite and to you as well, Sreetanwi.

\section{Poems by Santosh Alex}

\section{Grandma}

My family members

Remember her once in an year

She died when I was a kid.

They believe

She would re incarnate as

Seed

Breeze

Rain

Moon light.

Today was her anniversary

Her photograph hung on the wall

Was cleaned,

Small garland was placed

On it.

\section{Relatives arrived}

Note: This is an interview and there is no citation or works cited required. It is a live interview taken by Sreetanwi Chakraborty, Chief-Editor of Litinfinite Journal. 
Litinfinite Journal

ISSN: 2582-0400 [Online]

CODEN: LITIBR

Vol-2, Issue-1 ( $2^{\text {nd }}$ July, 2020)

Page No: 62-67

DOI: 10.47365/litinfinite.2.1.2020.62-67

Section: Interview

Offered their prayers

Had their lunch

Chit chatted for a while

And left.

I was trying to recollect

Her face

All of them say

I look like her.

\section{Suggested list of reading}

Alex, Santosh. Basheer: Three Short Novels. Delhi: Authorspress, 2019. Print.

Alex, Santosh. Laldyad. Delhi: India Netbook, 2019. Print.

Alex, Santosh. Pita Mere. Delhi: India Netbook, 2020. Print.

Alex, Santosh. Samkalin Malyalam Kahaniyan. Delhi: Sahityashila Prakashan, 2012. Print.

Alex, Santosh. Hindi Ki Sahityethar Bhumika. Delhi: Authorspress, 2018. Print.

Note: This is an interview and there is no citation or works cited required. It is a live interview taken by Sreetanwi Chakraborty, Chief-Editor of Litinfinite Journal. 